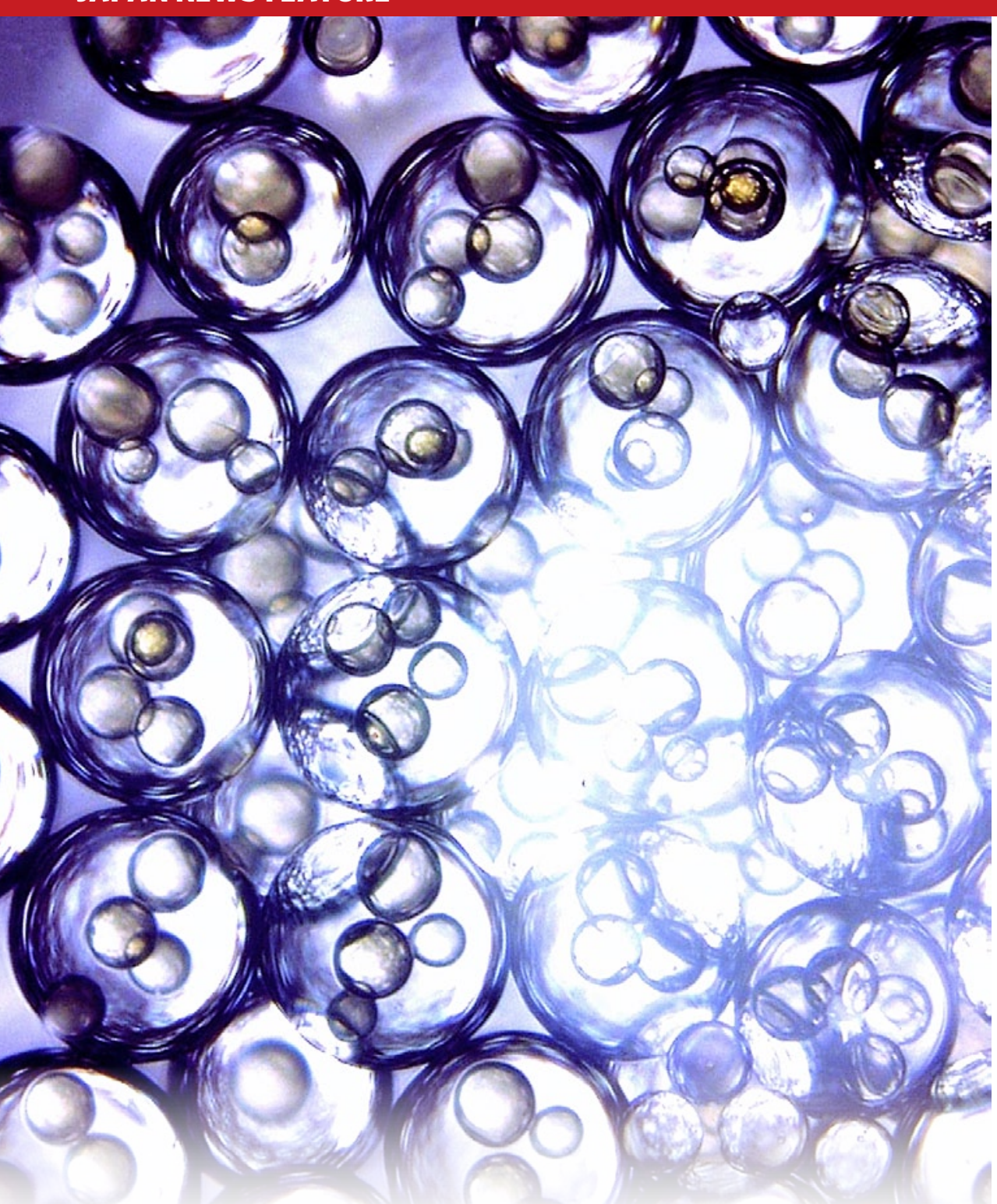

脂質と水が分離することで生じた大小の「泡」。大きい脂質の泡の中に小さい水の泡が含 まれている。これらを細胞の容器に使おうと東京大学の竹内昌治准教授らが研究中である。

\title{
「細胞を創る」ことで 生命を知る
}

藤川 良子 (サイエンスライター)

生命とは何かを探究する新しい研究会が日本に誕生したー「『細胞を創る』 研究会」である。分子生物学やゲノム科学に端を発したその活動は、「つく る」をキーワードにさまざまな専門分野に広がり、社会科学や文化芸術に まで範囲を拡大しようとしている。「つくる」という方法が、人々を引きつけ ているのだ。それはなぜ? そして、それによってどのような研究の進展が 期待できるのだろうか?

中世の説話集『撰集抄』には、興味深 い話が載っている。西行法師が、高野 山で骨を並べて護摩を焚き、人間をつ くってみた。しかし、うまくできなかっ たので捨ててしまい、つくり直そうとし ているうちに、恐ろしくなって止めたと いう内容。西行は 12 世紀ごろの歌人 であるから、この話によれば、日本でも 人は古くから生命を人工的につくり出す ことに興味をもっていたことになる。

そして、2007 年 11 月、日本の若 手研究者たちが「『細胞を創る』研究会」 を立ち上げた。『撰集抄』の時代とは異 なり、今や細胞をつくる研究にはリアリ ティがある。しかし、疑問も浮かぶ。ど のような細胞をつくるのだろうか? ど うやって? 細胞をつくっても問題ない のだろうか?

「まさにそれを知ろうとするのが、こ の研究会なのです」。この研究会の生み の親の 1 人、理化学研究所発生. 再生 科学総合研究センターの上田泰己チー ムリーダーはそう答える。細胞をつくろ うとする研究を通じて、細胞とは何か、 生命とは何かを考えていこうとしている のだという。

\section{つくろうとする試みがもたらすもの}

上田博士が、「今後の生物学は、つく る方向に進むだろう」と、周囲の人た ちに熱心に語り始めたのは、2005 年 ごろのことである。観察や分析を主体 にした研究から、「つくってみて仮説を 検証すること」が、今後の研究では主 流となってくるだろうということなのだ。 ちょうどこの 2005 年、生物時計の研 究で大きな発見があった。生物時計と は、生物の体内で時を刻む仕組みのこ とだが、名古屋大学の近藤孝男教授の チームが、単細胞生物シアノバクテリア の生物時計の正体を明らかにしたのだ。 すなわち、シアノバクテリアのもつ $3 つ$ のタンパク質を試験管中で混合すると、 24 時間周期で繰り返される化学反応が 生じた。リズムを刻む生物時計をつくる ことに成功したのである ${ }^{1}$

「『細胞を創る』研究会」のコアメン 
バーでもあり、近藤研究室で生物時計 の解明に携わってきた早稲田大学の岩 崎秀雄准教授は、当時を振り返る。「そ の3つのタンパク質が重要であることは わかりましたが、それで十分なのか、あ るいは、まだほかにも重要な部品があ るのか、なかなか確証が得られません でした」。だが、時計の働きをつくり出 すことにより、この3 つで十分であるこ とを、誰の目にも明らかにしたのである。

上田博士は、つくるという研究手法の 威力を人々に印象づけた研究成果の例 として、このシアノバクテリアの生物時 計の再構成と、京都大学の山中伸弥教 授の iPS 細胞（人工多能性幹細胞）を 挙げる ${ }^{2}$ 。山中教授は、体細胞に 4 つ の遺伝子を加えることで、多能性の幹 細胞をつくり出した。「検証方法の終着 点の 1 つは再構成であることを象徵す る研究です」と上田博士はいう。「例え ば、生命や細胞の研究において、遺伝 子やタンパク質といった “部品”の解 明をいつまで続けたらいいのだろうかと 考えたとき、部品を組み立てて細胞の 機能を再現できるまでが 1 つの目安と なるのではないか。今後の生命科学の 研究においては、こういう方法が、重 要になってくるのではないでしょうか」。

\section{多様性と専門性が実を結ぶコミュニティ}

2005 年末、上田博士は「『細胞を創る』 研究会」の前身である勉強会をスタート させた。「私自身は自分の研究テーマで ある、哺乳類の生物時計を再構成する という点から、『つくる』ことに興味をもっ たのですが、実にさまざまな分野の人が それぞれの立場で関心を寄せてくれるの に驚きました。そこで、それぞれの立場 や得意分野を背景に、みんなで集まって、 『つくる』ことの現状と未来を話し合う 勉強会を開くことにしたのです」。

上田博士は、生物の高次機能を「シ ステム」としてとらえ、解析していこう というシステム生物学者であるが ${ }^{3} 、$ 勉 強会に集まった研究者は、遺伝子の転 写・翻訳や複製、細胞のエネルギー代 謝やシグナル伝達、細胞分裂や細胞分
化、RNA工学、核酸合成、人工遺伝 子回路設計など多彩であった。さらに 生物学・医学だけにとどまらず、化学、 物理学、情報学、工学などの専門家も 参加して、勉強会は多様かつ専門性の 高いコミュニティとなった。「所属する学 会が違い、なかなか出会うことのない 研究者たちに、ここでなら会える」「他 分野の人たちの発想は、新鮮で刺激的」 と、参加者の多くが好意的に評価する。

勉強会での刺激的な研究発表を 2 つ、具体的に紹介しよう。1つは、大 阪大学四方哲也教授の実験進化学。教 授は、「地球上の生物にはこだわりま せん。生命のモデルを実験室でつくり、 進化の原理を調べたい」と話す。地球 上の生物は、偶然にそろった条件で誕 生し、複雑な進化を経て現在に至って いる。偶然性と再現不能な外的条件か ら生じた現存生物の研究からだけでは、 基本的な生命進化の原理が理解できる とは限らない。そこで、現存生物の分 析ではなく、より簡単な条件で人工生 命を創出し、その原始生命誕生と進化 の原理を探るというのが、四方教授ら

(a)

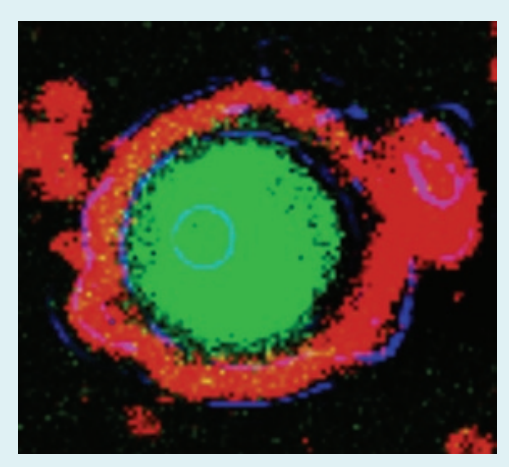

(b)

の発想である。人工生命ならば、さま ざまな初期条件で進化実験を行うこと ができ、仮説の検証ができるはずとい うわけだ。そこで、四方教授のグルー プは研究する際、生命の特徵を再現し た人工細胞モデルブくりに時間を費や してきた。人工細胞モデルには、リポ ソームとよばれる小胞を容器として利用 する。リポソームは、実際の細胞と同 じように脂質の二重膜からなり、細胞 膜を模倣するときによく使われる。この 小胞の中に、DNA や RNA、アミノ酸、 ATP 分子など、細胞の部品を入れる と、遺伝情報からタンパク質がつくられ る(図 1a) 4 。

現在の細胞生命につながる原始細胞 は、どれくらいの大きさで何種類の部 品が集まってできていたのであろうか?

「机上で考えるのは簡単ですが、この 人工細胞モデルの中で、生命の特徵で ある遺伝情報の自己複製反応を再現す るだけでも 10 年かかりました」と、四 方教授は原始細胞を誕生させるむずか しさを語る。遺伝物質（RNA）から複 製酵素タンパク質がつくられ、その酵素

図 1 生命の特徵的な反応を再現させた人工細胞。

リポソームに遺伝物質（DNA や RNA）やアミノ酸、エネルギーとなるATP などを封入し、タンパク 質の合成や遺伝物質の複製などの反応を自発的に引き起こす工夫が行われている。大阪大学の四方哲 也教授のグループは、機能性のあるタンパク質をリボソーム中で合成することに成功した ${ }^{4}$ 。(a) の写 真はタンパク質の合成反応を緑の発色で確認している例。赤色は染色されたリポソーム。(b) は遺伝 子の自己複製の模式図。遺伝物質（RNA）から翻訳されて生じた複製酵素が元の遺伝物質を複製す るという反応回路をつくることができた。複製反応が起きていることは、遺伝物質を逆向きに翻訳した ときにつくられる酵素（図では $\beta$ - ガラクトシダーゼ）の反応で確認された。 
が元の遺伝子情報のコピーつくり、自 己複製反応が完了する(図 $1 b) 。$ 四方 教授のグループはさまざまな試行錯誤 のなかで、最終的に、144 種類の成分 と、約 5000 もの反応ステップが必要 なことを突き止めて、遺伝子自己複製 を行う人工細胞をようやく誕生させた。 原始細胞モデルのサイズに関しても、 直径 $3 \mu \mathrm{m}$ 程度が適当であるとわかっ た。「サイズが小さすぎるとすべての材 料が入らず、大きすぎると、合成され た複製酵素が遺伝情報に出会わず複製 しません」。この原始細胞モデルでは遺 伝情報の突然変異が自然に起こるので、 四方教授らはさらなる進化実験のアイデ アを練っている。

上田博士によれば、「研究会では、現 存細胞の機能を再構成しようとする立 場を天然系、四方教授のように人工細 胞のモデルを合成して実験しようという 立場を人工系と便宜的によんでいます。 両者が刺激し合えるところが大きい」そ うだ。その 1 つの成果ともいえるのが、 上田博士が最近作成した細胞システム だ。マウスの培養細胞の中に人工の遺 伝子ネットワークを挿入し、天然の生物 時計の仕組みを実際にシュミレーション し検証できるようになっている。

\section{技術の革新と工学分野の参加}

上田博士の場合も四方教授の場合も、 生命の原理を探ろうとする研究だが、 次に紹介する東京大学生産技術研究所

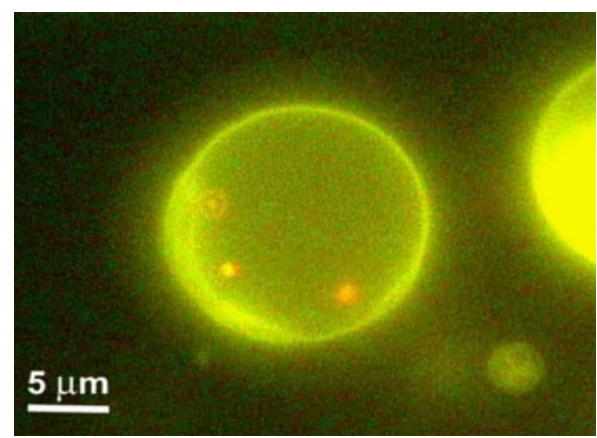

図 2 リポソーム (人工の小胞)。脂質二重膜で囲ま れている微小な容器。東京大学の竹内昌治准教授ら は、同じサイズのものを簡単かつ大量に作製できる 方法を研究中である。「直径を小さくする工夫は今後 の課題」という。
の竹内昌治准教授は、まったく異なる 点でこの会に魅力を感じている。「細胞 と同じくらい高度な動きもった機械や、 細胞と同じくらい感度のよいセンサー は、いまだかつて存在しません。だか ら、細胞の機能をきちんと制御すれば、 すばらしい機械ができるでしょう」と楽 しそうに語る。

竹内准教授にとって、「動くセンサー」 をつくることが当面の目標である。その 動く仕組みとしては鞭毛が、センサーと しては細胞膜に存在する膜タンパク質が 考えられている。鞭毛は、ミドリムシな どの藻類や動物の精子などに生えてい るひも状の器官で、タンパク質の繊維 からなり、ATP などのエネルギーを与 えると自発的にムチのように動く。「そ の複雑な動きは、機械屋が見るとたまり ません。リポソームにつければ動く人工 細胞がつくれます」と、竹内教授はそ の利用に意欲を示す (図 2) 5。また、 細胞の膜には、細胞の内と外でイオン のやり取りをする細孔（チャンネル）が ある。この穴の開閉は膜に埋め込まれ たタンパク質が制御しており、分子 1 個 の存在さえも感知して反応し、イオン電 流を流すことができる。したがって、「高 感度のにおいセンサーや味センサーな どに使える可能性があります」と竹内准 教授は説明する。

細胞の機能を工学的に利用するとき には、同一の規格のものを大量に用意 するということが重要であるが、膜タン パク質の場合は、すでにそれが可能だ。 つまり、直径 $30 \mu \mathrm{m}$ という微小な穴に、 培養液と膜タンパク質をもった膜断片を 入れてつくり出すのだが、その穴をチッ プ (基板) 上に多数つくることに成功し ている ${ }^{6}$ 。各穴の電位を測定することも 可能なのだ（図 3)。

「大量生産には、工学的な発想や技 術を最大限に生かしたい」と竹内准教 授はいう。特に、微小な装置の加工が 可能になった背景には、MEMS (Micro Electro Mechanical System) とよ ばれる半導体微細加工技術の飛躍的な 発達がある。生物学の研究においても
技術の発達は欠かせない。微小な反応 装置を大量に作製できるMEMS は、注 目される技術の筆頭だろう。このコミュ ニティは、生物学者にとって新たな技術 と出会える場所でもある。

また、竹内准教授も語る。「工学と生 物学のバイリンガルをめざしている私た ちにとって、この会を通じて生物のこと を学べるので助かります。両者は目的 が違っても、触発し合ったり、協力し合っ たりできることが実に多いのです」。

\section{合成生物学の流れのなかで}

2008 年 1 月、米国のクレイグ・ベン ター研究所は、細菌のゲノムを合成する ことに成功した ${ }^{7}$ 。ゲノムプロジェクトで 解読された配列情報を元に、遺伝子の 連なった長いDNA 分子の全長を実際 に組み立てたのである。これを細胞に 戻せば、「人工のゲノムをもつ生命体の 合成も間近だろう」と、カリフォルニア 大学のChristopher Voigt 准教授は いう。Voigt 准教授は、有用な働きを する遺伝子の新たな組み合わせを設計 する研究を行っている。

このように、「つくる」生物学は国際 的にも活発化している。「合成生物学(あ るいは構成的生物学)」とよばれる研究 分野として発展し、2004 年より、国際 学会も開かれている。こうした動きに 注目してきた東京大学の菅野純夫教授 は、「合成生物学は米国において、ゲノ ム研究の流れの先にあるものという色 彩が強いです。日本の生物学において、 原理探求の方法として合成や再構成は、 重要ではあろうが、どこまで主流になる のかはよくわかりません」と語り、さら に「将来、応用面では役に立つ成果が 期待できると思います。ミニマムゲノム プロジェクトのように、細菌の遺伝子を 最低限に減らして、その細菌に、有用 遺伝子群を含んだミニゲノムを挿入しよ うという試みは既に始まっています」と 続ける。がん組織は低酸素状態にある ので、がんの治療に嫌気性細菌を利用 するとか、鉄酸化細菌にゴミを食べさせ て細菌体内から鉄を回収するといった多 


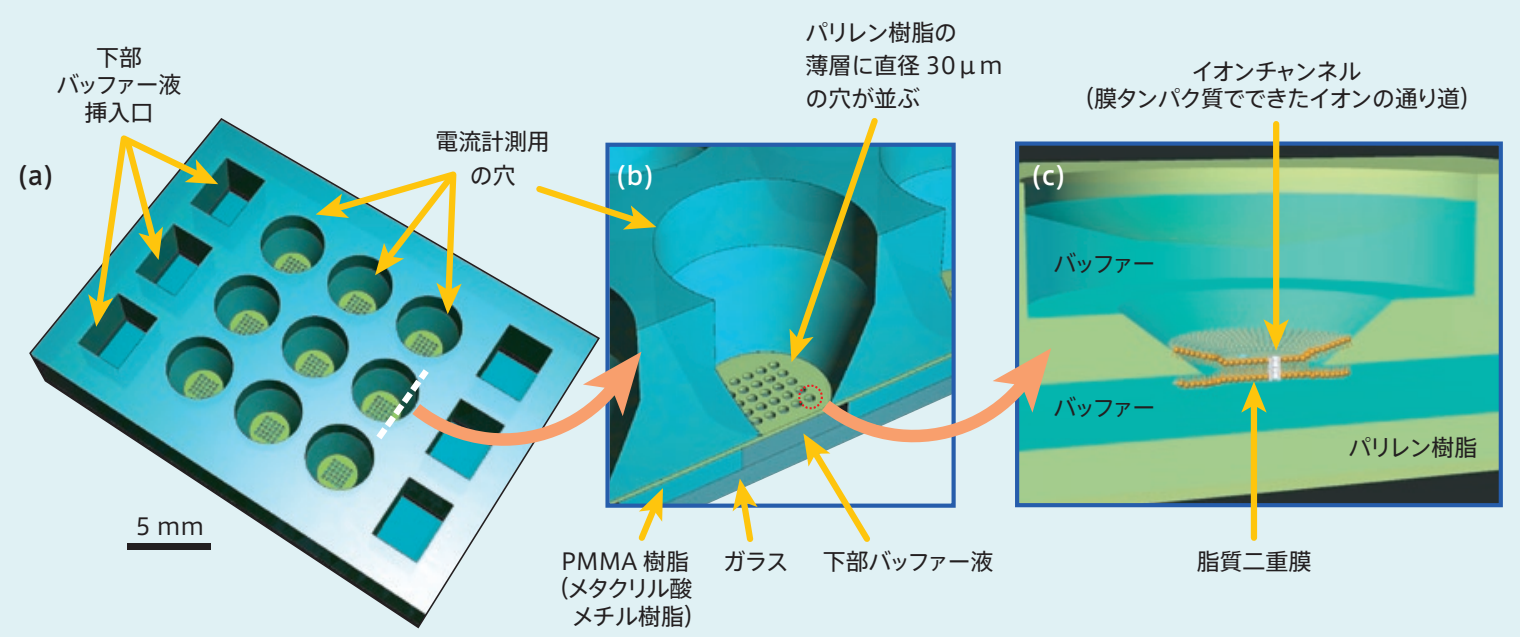

図 3 イオンチャンネルを利用した電流計測マイクロデバイス。

東京大学の竹内昌治准教授らが開発した微小な電位差を感知できる装置。(a) マイクロチップ (基板) 上に複数の測定単位（穴）を並べ、高効 率の計測を実現。(b) 穴の中には、イオンチャンネルを備えた樹脂薄膜が設置されている。その上部はバッファー（緩衝液）で満たされており、 電流が測定できる。(c) 樹脂薄膜の各穴は 1 個のイオンチャンネル (イオンの通り道) に相当する。イオンチャンネルは、バッファーと脂質溶液を 交互に入れることで作製した膜に、タンパク質を挿入してつくる。樹脂の材質や形状が工夫されている。

彩なアイデアが、合成生物学の研究か ら発展する可能性がある。

これに対し、上田博士は、「生命の謎 を解く基礎生物学にとっても、つくると いう方法が重要であると、多くの若い研 究者が考えています。山中教授のiPS 細胞創出成功の影響も大きいでしょう」 と語る。「欧米の合成生物学会はもとも と工学分野から誕生したこともあり、応 用的な面が強すぎると感じています」と も付け加える。

「細胞をつくることは許されるか」の前に 「細胞を創る」研究会では、「つくる」 をキーワードに集まるさまざまな分野 の研究者による横のつながりを大切に し、コミュニティとしての役割を重要視 している。

特にこの研究会の大きな特徴は、「社 会・文化ユニット」が中心的な活動の 1 つに位置づけられていることだろう。 生物やその一部をつくり出そうという研 究に対しては、当然ながら、「許される ことだろうか?」「危険性はないだろう
か?」と人々は不安になる。研究会で は、第 1 回目の勉強会のときからこの ユニットを立ち上げて、こうした倫理的. 社会的な問題を検討してきていた。そ のリーダーである岩崎准教授は、「当面 は差し迫った危険があるという状況では ないので、まずは、細胞をつくる意味 や生命とは何かについてしっかり議論を していきたいですね。そもそも、細胞 をつくるとはどういうことか、何をつくっ たら細胞をつくったことになるのか。そ のようなことすら、わからないのですか ら」と説明する。生命とは何かの根本 的な議論を重ねることがまず重要という ことだ。そしてそのうえで、研究を規制 するルールを体系的に作成したいとい う。また、「大規模なアンケートなども 実施したい。ただ、これまでこの研究 会の運営はコアメンバーの手弁当で進 めてきたので、今のところは無理です が。また、生命倫理学を専門とする人 材が日本では不足しています」と指摘す る。京都大学生命倫理分野の加藤和人 准教授が、会のコアメンバーとしてこの
ユニットを支えているが、今後活動が本 格化すると、専門家のマンパワー不足 が心配される。海外のグループとの連 携やウェブを使ったオンライン・ディベー トシステムの設置など、このユニットが 日本で先導的な役割を果たすようにな るためには、活動を充実させていくこと が求められるからだ。

また、「議論は科学者や生命倫理の 専門家だけで行うのではなく、一般の 人にも参加してもらう機会をつくり、社 会的、文化的な興味からも論じていき たい」というのが、会の一貫した方針だ。 会の多彩なメンバー構成が、その役に 立っている。科学哲学や市民生活の研 究者、芸術家との交流もある。「バイオ アートという現代芸術もあります。マイ クロアレイや細胞や遺伝子を操作するバ イオテクノロジーの技術が、芸術の表現 方法やモチーフとして関心をよんでいる のです」と、実は自身が切り絵アーティ ストでもある岩崎准教授は説明し、「生 命の見方が多面的になる相互作用が生 じればいい」と期待している。 


\section{社会の中でのコンセンサスづくりを}

勉強会が研究会に発展し、その初代会 長の席には四方教授がついた。「私が 最年長で、会のコアメンバーはほとんど が 30 代以下の若手。この会を通して 若手をサポートしたい」と述べる。今 後は、年 1 回のペースでシンポジウム を開く予定である。第 1 回は2008 年 10 月 16 日から 2 日間、大阪大学を会 場に開催される。ポスター発表を中心 にし、対話と議論に重きが置かれる。「生 命観は、科学者と市民が働きかけ合う ことで形成される」と、四方教授は活 発な議論の展開を期待している。

また、このシンポジウムに合わせ、直 前の 10 月 14 日から2 日間、理化学 研究所発生·再生科学総合研究センター 主催の国際会議「細胞の創出に向かって (Towards Synthesis of Cells)」も 開催される。こちらは、前出の近藤教授 や山中教授、細菌ゲノムを合成した C.ベ ンター研究所の Clyde A. Hutchison 博士らの講演が予定されている。

「今後は、分子から細胞をつくるだけ でなく、脳のような高次機能組織を細胞

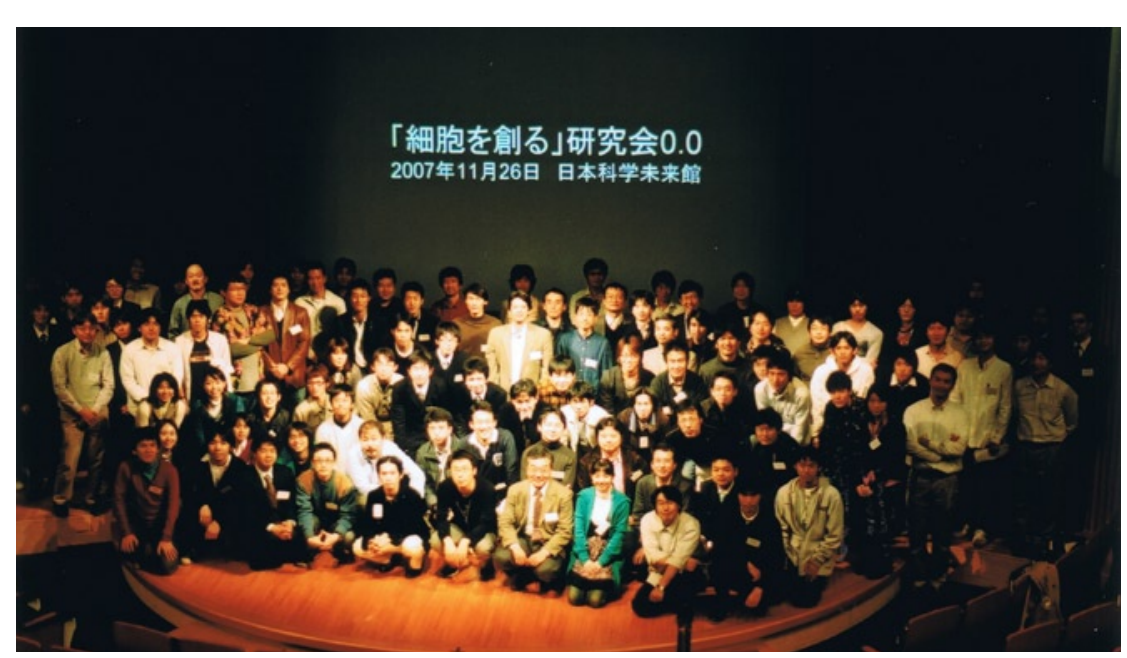

2007 年 11 月に行われた「細胞を創る」研究会の発足式で。

から発生させてつくったり、翻訳酵素の ような複雑な分子複合体を原子から人 工的に設計してつくったりと、つくる範 囲がさらに広がっていくでしょう」と上 田博士は語る。

もちろんそのためには、技術の開発 はもとより、「生命とは何か」「つくるこ とは何を意味するか」についてのしっか りしたコンセンサスを社会の中で築き上 げていかなくてはいけないだろう。今度
は、西行法師のように途中で止めること ができないだろうから。

1. Nakajima, M. et al. Science 308, 414-415 (2005)

2. Takahashi, K. et al. Cell 30, 861-872 (2007)

3. Ukai, H. et al. Nature Cell Biology 9, 1327-1334 (2007)

4. Yu, W. et al. J. Biosci. Bioeng. 92, 590-593 (2001)

5. Funakoshi, K. et al. J American Chemical Society 129, 12608-12609 (2007)

6. Tan, W-H. and Takeuchi, S. Proc Nat Academy Sciences 104, 1146-1151 (2007)

7. Gibson, D. G. et al. Science 319, 1215-1220 (2008)

\section{Be Global

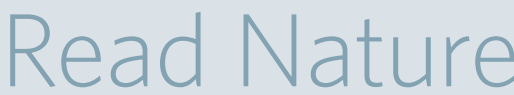

創刊から 139 年、変わらぬ NATURE'S MISSION

研究者のニーズに合わせ、時代に合わせ進化した Nature コンテンッ

研究者に求められるすべての要素が Natureにはある

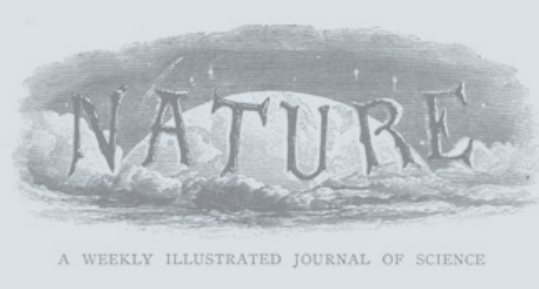

NATURE'S MISSION, 1869:

'The objective which it is

proposed to attain by this

periodical may be broadly stated

as follows. It is intended, first, to place before the general public the grand results of scientific 